\title{
Vieses jornalísticos sobre o conceito de família à luz da teoria dialógica do discurso
}

\section{Journalistic biases about the family concept from the dialogical theory of discourse}

Fernanda Pinheiro de Souza e Silva ${ }^{1}$
Herman Wagner de Freitas Regis

Recebido em: 03/02/2020

Aprovado em: $31 / 08 / 2020$

Publicado em: 20/12/2020

RESUMO: Este artigo analisa os movimentos discursivos e dialógicos de três instituições midiáticas: as revistas Gospelmais, Carta Capital e Fórum. Elas abordam sobre o conceito de família com o intuito de ponderar como refletem ou refratam o modelo hegemônico constitucional de família. O referencial teórico será embasado através da Teoria Dialógica do Discurso (BAKHTIN, 1993, 2008, 2011; VOLÓCHINOV, 2017), em virtude de fornecer à pesquisa um instrumental teórico pautado na investigação de sentidos de textos concretos. No caso presente, far-se-á a análise de gêneros jornalísticos, analisando-os a partir das relações dialógicas desses discursos com outros discursos pelo Dialogismo de Bakhtin.

Palavras-chave: Teoria Dialógica do Discurso; Gêneros jornalísticos; Conceito de família.

\begin{abstract}
This article analyses the discursive and dialogical movements of three media institutions: the magazines Gospelmais, Carta Capital and Fórum. They approach about the family concept with the purpose to consider how these magazines reflect or refract the constitucional hegemonic model of family. The theoretical framework will be based on the Dialogical Theory of Discourse (BAKHTIN, 1993, 2008, 2011; VOLÓCHINOV, 2017) by virtue of provides the research with a theoretical instrument based on the investigation of meanings of concrete texts. In the present case an analyze of journalistic genres will be made analyzing them based on the dialogical relations of these discourses with others discourses through Bakhtin's dialogism.
\end{abstract}

Keywords: Dialogical Theory of Discourse; Journalistic genres; Family concept.

1. Licencianda em Língua e Literatura Portuguesa e Inglesa. Especialista em Leitura, Compreensão e Produção Textual. Especialista em Linguística Aplicada a Práticas Discursivas. Mestre em Ciências da Linguagem pela Universidade Católica de Pernambuco. Doutoranda no Programa de Pós-Graduação em Ciências da Linguagem na Universidade Católica de Pernambuco. ORCID: 0000-0003-3941-3913 E-mail: fernandapssletras@hotmail.com

2. Graduado em Letras pela Universidade Federal do Ceará. Mestre em Educação pela Universidade Católica de Petrópolis. Doutorando em Ciências da Linguagem pela Universidade Católica de Pernambuco. ORCID: 0000-0002-6912-6627 E-mail: profhermanregis@yahoo.com.br 


\section{INTRODUÇÃO}

Não se fazem mais comerciais de margarina como antigamente: pai, mãe e filhos ao redor de uma farta mesa de café da manhã. O modelo tradicional de família que, em 1995, correspondia a, aproximadamente, $58 \%$ das famílias brasileiras passou para 42\%, na Pesquisa Nacional por Amostra de Domicílios (PNAD) de 2015, ou seja, formatos diferentes de família já são maioria. Mulheres sozinhas com filhos, pais divorciados que constituíram novas famílias, crianças adotadas por casais homoafetivos ou por mulheres solteiras, entre outras, são algumas das configurações que vemos cada vez mais na sociedade atual.

O censo de 2010 mostrou o comportamento das famílias brasileiras e registrou que $12,2 \%$ delas são unipessoais (formadas por um homem ou uma mulher morando sozinho); $66,2 \%$ são nucleares (formadas por casal com filhos, casal sem filhos, mulher com filhos ou mesmo homem com filhos); $19 \%$ são estendidas (formadas por famílias constituídas por casal com filhos mais parentes, ou casal sem filhos e com parentes); 2,5\% são compostas (formadas por casal com não parentes, ou mulher ou homem com não parentes). Essa pesquisa revelou que as identidades familiares estão mudando.

Segundo Stuart Hall (2000, p. 108), na modernidade presente, tardia, as identidades não são nunca unificadas ou singulares; elas são cada vez mais fragmentadas, construídas de forma múltipla de discursos, práticas e posições muitas vezes antagônicas. Para Hall (2000), as identidades estão sujeitas a uma historicização radical, estando constantemente em processo de mudança e transformação e argumenta que:

As identidades têm a ver não tanto com as questões 'quem nós somos' ou 'de onde viemos', mas muito mais com as questões 'quem nós podemos nos tornar' e 'como essas representações afetam a forma como nós podemos representar a nós próprios'.[...] [As identidades] surgem da narrativização do eu, mas a natureza necessariamente ficcional deste processo não diminui, de forma alguma, sua eficácia discursiva, material ou política [...] (HALL, 2000, p. 109).

Diante desse contexto de reconhecimento de novas formações familiares, esta pesquisa surge com o intuito de analisar os vieses midiáticos sobre o tema referido, procurando compreender como essas versões de fatos acontecem discursiva e linguisticamente, além de questionar o posicionamento ideológico dos meios de comunicação no sentido de que, em muitos momentos, eles esquecem o interesse da maioria da população para satisfazer o interesse do seu público leitor.

Nesse sentido, Marcuschi (2008) entende que cabe ao homem, na interação social, compreender o mundo pela inferência, e não como algo a ser decodificado, retirado de forma única e objetiva. Assim pode-se tomar a hipótese de que o discurso 
SILVA, F.P.S.; REGIS, H.W.F.

jornalístico tem a pretensão de levar a informação per si como algo objetivo, em que caberia ao leitor decodificá-la ipsis litteris, deixando de lado suas inferências e seus conhecimentos de mundo.

Intenta-se, dessa forma, refletir sobre as estratégias discursivas que norteiam as revistas Gospelmais, Carta Capital e Fórum acerca do conceito de família, discutido no Congresso Nacional e reverberado na mídia. Sobre o tema de investigação, o deputado e evangélico Anderson Ferreira, autor do Projeto de Lei ํㅜ 6.583/13, leva ao Congresso Nacional o projeto do Estatuto da Família, que defende um conceito tradicional de família: nele, a instituição familiar é constituída pela união entre um homem, uma mulher e filhos. O referido Projeto de Lei (PL) parece não considerar as mudanças sociais em termos de estrutura familiar e ainda restringe os direitos civis como a adoção e a previdência somente aos casais tradicionais.

Diante dessa discussão, no Congresso Nacional e na sociedade sobre o conceito de família que deve ser legitimado, percebe-se que a mídia cultiva em seus leitores versões axiológicas, valorativas, distintas também. Mais especificamente, objetiva-se aqui identificar, compreender e comparar as estratégias linguísticas e discursivas que as revistas on-line, representadas por seus jornalistas, utilizam para refratar (combater) ou refletir (defender) o PL no 6.583/13.

O tema delineado neste artigo é descrito à luz da Teoria Dialógica do Discurso (BAKHTIN, 1993, 2008, 2011; VOLÓCHINOV, 2017), que considera a linguagem como situada na interação sócio-histórica, não considerando a língua de forma abstrata, ou seja, fechada nela mesma. A linguagem, segundo Bakhtin (2008), só vive na comunicação dialógica daqueles que a usam e é sempre um evento único, visto que o enunciado nunca se repete, pois está inserido dentro da realização histórica real de eventos discursivos ímpares.

A justificativa, ora apresentada, reflete o posicionamento do pesquisador, de forma ativa e engajada, no sentido de pretender detectar as vozes e os seus valores que constroem o evento e os momentos discursivos em termos de produção de sentido a favor ou contra o conceito de família tradicional.

\section{Referencial teórico}

Esta pesquisa foi desenvolvida sob a égide da Teoria Dialógica do Discurso, operando, principalmente, com os pressupostos do Círculo de Bakhtin já referenciados anteriormente, defendendo a linguagem como sendo realizada na interação verbal, contrapondo-se a outras concepções de linguagem, em que a língua é vista de forma 
monológica, como um produto acabado, sem relação com o contexto sócio-histórico (VOLÓCHINOV, 2017). Assim sendo, a linguagem é vista a partir da interação entre os indivíduos envolvidos numa prática social. Para Volóchinov,

a verdadeira substância da língua [...] é constituída [...] pelo fenômeno social da interação verbal, realizada através da enunciação ou das enunciações. A interação verbal constitui assim a realidade fundamental da língua. [...] Mas pode-se compreender a palavra - diálogo, num sentido amplo, isto é, não apenas com a comunicação em voz alta, de pessoas colocadas face a face, mas toda comunicação verbal, de qualquer tipo que seja (2017, p. 218).

As ideias de Jakubinskij, no sentido de que qualquer comunicação verbal acontece na interação, no diálogo são aportes teóricos de sustentação do que propomos neste artigo, em relação, principalmente, à questão da massa aperceptiva do ouvinte, em que Jakubinskij assevera que há uma maior compreensão do discurso do locutor pelo interlocutor quando há muito em comum nas massas aperceptivas de ambos, o que possibilita um maior uso de alusões e de enunciados incompletos. Inversamente, quanto menos essas massas tiverem em comum, maior a dificuldade de intercompreensão (JAKUBINSKIJ, 2015, p. 97).

As contribuições de Volóchinov (2017) para o presente questionamento, relacionadas à ideologia e ao signo ideológico, são também imprescindíveis. Ele afirma que não há uma única definição do termo ideologia, mas diversas definições, todas elas complementares, elaboradas de um ponto de vista distinto. Essas definições consideram a ideologia enquanto elemento estrutural da sociedade e, por sua vez, no campo de signos (tudo o que é ideológico possui valor semiótico) são representações do real (VOLÓCHINOV, 2017).

Com base em Bakhtin (1993), abordamos, neste estudo, o dialogismo como recobrindo um campo amplo, colocando a enunciação no centro das relações interdiscursivas (dialogismo interdiscursivo) e o enunciado no contexto imediato e na sua história (dialogismo interlocutivo). Toda enunciação é apenas "um elo na cadeia da comunicação discursiva" (BAKHTIN, 2011, p. 279) e o enunciador não é a única fonte do enunciado nem dos sentidos.

Para os estudos dos gêneros jornalísticos da pesquisa, é fundamental considerar a noção de gênero proposta por Bakhtin (2011). Ele relaciona os gêneros com as esferas discursivas, definindo-os como tipos de enunciado relativamente estáveis, que refletem as condições específicas e as finalidades de cada uma dessas esferas, não só por seu conteúdo (temático) e por seu estilo verbal, ou seja, pela seleção operada nos recursos da língua - recursos lexicais, fraseológicos e gramaticais, mas também, e sobretudo, por 
SILVA, F.P.S.; REGIS, H.W.F.

sua construção composicional, sendo o gênero, portanto, historicamente situado, extremamente heterogêneo do ponto de vista da estrutura composicional, mas flexível. (BAKHTIN, 2011).

Por fim, nas análises, além do aspecto lexical, do gênero e da massa perceptiva, será observada a polifonia, ou seja, as diversas vozes existentes nos textos interagindo com suas respectivas ideologias numa arena semiótica e axiológica. A partir de agora, serão apresentadas as categorias de análise do corpus.

\section{Enunciado, enunciação e nomeação}

Conforme Bakhtin (2011), não há como compreender um enunciado fora do seu contexto de produção, ou seja, não há como compreender nem fazer uso de um gênero sem conhecer e compreender as suas possibilidades e os seus limites em seu contexto de produção, circulação e recepção. A experiência discursiva de cada sujeito é constituída no processo constante e contínuo de interação com os enunciados de outros sujeitos. Nesse sentido, o enunciado é uma unidade da comunicação discursiva dotada de sentido, relacionado com valores de verdade, de beleza, que exige, justamente por isso, uma compreensão responsiva, um juízo de valor. Esse tipo de manifestação por parte do usuário da língua é denominado postura ativa, ou seja, o domínio do gênero requer de nós usuários esse tipo de postura, afinal, quanto melhor dominamos os gêneros tanto mais livre os empregamos (BAKHTIN, 2011).

Nessa direção, o enunciado, como categoria na pesquisa, será materializado pelas formas discursivas em que os signos aparecem, mais claramente pela nomeação. Segundo Sophie Moirand (2006), o processo da nomeação é, constitutivamente, formado pela alteridade. De acordo com Paul Siblot (1998), toda nomeação do outro tem por finalidade evidenciar por parte daquele que nomeia uma posição sobre o que é nomeado. E ela fica visível no léxico. Para o autor, a práxis linguística inserida numa cadeia contínua de práxis diversificada, retira dessas últimas as informações que lhes servem para elaborar o "conteúdo semântico" das categorias lexicais.

\section{Gênero discursivo}

De acordo Bakhtin (2011), as variadas formas dos gêneros são determinadas conforme as diversas finalidades que assumem em uma dada esfera de comunicação discursiva, isto é, em função da situação de produção, da posição hierárquica e das relações de interação entre os interlocutores da comunicação. Consoante Bakhtin (2011), cada gênero se organiza pela constituição de três elementos inseparáveis: a forma composicional (modo de organização do texto), o conteúdo temático e o estilo (recursos 
SILVA, F.P.S.; REGIS, H.W.F.

fraseológicos, a seleção lexical, a sintaxe), conforme os contextos e as situações específicas determinadas por cada esfera de comunicação discursiva.

Assim, o emprego da língua efetua-se em forma de enunciados (orais e escritos) concretos e únicos, proferidos pelos integrantes desse ou daquele campo da atividade humana. Esses enunciados refletem as condições específicas e as finalidades de cada referido campo, não só por seu conteúdo (temático) e pelo estilo da linguagem, ou seja, pela seleção dos recursos lexicais, fraseológicos e gramaticais da língua, mas, acima de tudo, por sua construção composicional. Todos esses três elementos - o conteúdo temático, o estilo, a construção composicional - estão indissoluvelmente ligados no todo do enunciado (BAKHTIN, 2011).

Neste artigo, observamos como os gêneros notícia e artigo de opinião se configuram perante a ideologia de cada revista, por meio de cada autor, sendo premissa para a análise. O tema debatido na sociedade, no Congresso Nacional e nas revistas, aliado ao estilo próprio da mídia com suas intenções e propósitos, gerará sentidos e valores díspares a serem observados.

\section{Polifonia}

A polifonia é um conceito muito caro à linguística contemporânea. Ela foi utilizada, metaforicamente, por Bakhtin, na análise da obra de Dostoiévski por considerá-lo o criador do romance polifônico (BAKHTIN, 2008). A multiplicidade de vozes e consciências independentes e imiscíveis e a autêntica polifonia de vozes plenivalentes constituem, de fato, a peculiaridade fundamental dos romances de Dostoiévski (BAKHTIN, 2008). A riqueza da polifonia, inerente a toda enunciação, é o embate de vozes que se expressam, que se opõem, que se assemelham, respeitando sempre seus lugares de enunciação. Nessa questão, Rechdan (2003, p. 46) adverte que o dialogismo não deve ser confundido com a polifonia, pois o dialogismo é o princípio dialógico constitutivo da linguagem, enquanto a polifonia se caracteriza por vozes polêmicas em um discurso. Podemos concluir que, nos gêneros polifônicos, há vozes tão polêmicas quanto as dos personagens dos romances de Dostoiévski, os quais funcionam como seres autônomos, com visão de mundo, voz e posição própria.

A princípio, a notícia e o artigo de opinião não teriam vozes que duelassem, mas veremos que o jornalista traz outros discursos, vindo de outras vozes, que apresenta no intuito de corroborar com o ponto de vista dele e da revista. Trazer a polifonia como categoria de análise é relevante por compreender que ela fornece visões ideológicas de 
SILVA, F.P.S.; REGIS, H.W.F.

mundo e, referindo-se mais especificamente à pesquisa, ela aborda opiniões a favor ou contra a definição de família tradicional.

\section{Constituição do corpus}

Para as análises que doravante faremos, optamos por um corpus restrito e outro ampliado. O restrito englobou a análise linguística e discursiva; já o corpus ampliado auxiliou em lançar luz sobre o restrito no sentido de serem observados nele os aspectos ideológicos e dialógicos do caminho percorrido pelas revistas. Porém, devido à limitação das laudas, fica impraticável transcrever o corpus ampliado e todo o material do restrito. Assim, o restrito aqui é formado por três textos: o primeiro, na sequência em que foram analisados, é uma notícia da revista Gospelmais e o segundo um artigo de opinião da revista Carta Capital que, devido esse ter extensão de uma página e aquele de duas, optamos por apresentá-los na íntegra. Porém, o terceiro, um artigo de opinião da revista Fórum, analisamos na íntegra os dois primeiros parágrafos para trazer uma análise mais geral que possibilitasse lançar um olhar sobre os demais parágrafos do texto dos quais foram extraídos apenas trechos para análise.

\section{ANÁLISE DO CORPUS}

1. Notícia1:

O projeto de lei apelidado como Estatuto da Família teve seu relatório aprovado na comissão especial que estuda o texto, e manteve o conceito familiar como o núcleo formado por um homem e uma mulher. O relator do projeto, deputado federal Diogo Garcia (PHS-PR), afirmou em seu parecer que uma família é "a união de um homem e de uma mulher, por meio de casamento ou de união estável, e a comunidade formada por qualquer dos pais e seus filhos”. A divulgação do parecer aconteceu na última quartafeira, 2 de setembro.

O Estatuto da Família, proposto pelo deputado Anderson Ferreira (PR-PE), é apoiado pelos parlamentares da bancada evangélica e visto como polêmico por boa parte dos partidos de apoio ao governo, de orientação esquerdista.

Para os críticos do projeto, seu texto é considerado equivocado por não considerar família as uniões entre pessoas do mesmo sexo e as relações poligâmicas, por exemplo. Outro argumento usado é a decisão do Supremo Tribunal Federal (STF) de proibir os cartórios de se recusarem a celebrar o casamento civil ou converter união estável em

\footnotetext{
1 Notícia extraída da Editora e Revista Gospelmais, de 03/09/15, sob o título Aprovado, relatório do Estatuto da Família reconhece apenas a união de homem e mulher. Por Tiago Chagas.
}

Revista do SELL, Uberaba/MG (online) - V. 9 n. 2, p. 298-316, jul./dez. - 2020. 
casamento de homossexuais. Garcia, ciente das críticas, usou um contra-argumento no relatório do projeto: "Trata-se de competência do Congresso Nacional regulamentar, para maior eficácia, a especial proteção constitucionalmente garantida à família.

O estatuto vem para colocar a família, base da sociedade, credora de especial proteção, no plano das políticas públicas de modo sistemático e organizado, como até então não se fizera. Nada impede que os cidadãos, mediante seus representantes políticos, advoguem pela inclusão de novos benefícios a outras categorias de relacionamento, mediante argumentos que possam harmonizar-se à razão pública".

Por fim, o parlamentar destacou que seu relatório foi formado a partir das impressões colhidas durante os debates e as audiências públicas, quando ouviu representantes da sociedade. O documento, segundo ele, está "alinhado aos preceitos constitucionais e valores morais e éticos de nossa sociedade, com o fim de garantir direitos e o desenvolvimento de políticas públicas para a valorização da família".

Análise:

a) Gênero discursivo: o próprio nome da revista, "Revista Gospelmais", já direciona o leitor ao conceito de família defendido por esta instituição midiática, o da família tradicional, cristã. O título da notícia inicia pelo particípio do verbo aprovar: aprovado. Em seguida, há uma pausa intencional evidenciada pela vírgula com o intuito de informar primeiramente o resultado da votação do Estatuto da Família foi aprovado - e, posteriormente, a complementação dessa aprovação, ou seja, foi aprovado o Estatuto que reconhece família como apenas a união entre homem e mulher. O primeiro parágrafo apresenta as duas informações principais: a aprovação do Estatuto e a essência dele, que é a formação de família segundo um conceito tradicional. O corpo da notícia reforça essa ideia e informa que o Estatuto é defendido pela bancada evangélica. Toda essa composição genérica ratifica a ideia de uma concepção de família tradicional defendida pela Revista Gospelmais e consequentemente pelos seus leitores, cujas valorações estão impregnadas de um teor bíblico-cristão, no qual qualquer outro conceito de família que não seja o tradicional não vale, não conta;

b) Polifonia: A única voz expressa pela citação direta é a do deputado Diego Garcia, relator do Estatuto, que vem para legitimar a notícia. Outras vozes que têm essa função de legitimação, como forças centrípetas que impedem o deslocamento do padrão tradicional de família, aparecem quando o Portal remete o Estatuto ao seu 
criador, o deputado Anderson Ferreira, e ao apoio da bancada evangélica. Todas essas vozes referidas anteriormente estão comprometidas com o Estatuto da Família de Anderson Ferreira. No penúltimo e no último parágrafo, surge a referência do Portal a outras vozes, que contra-argumentam em oposição ao discurso do Estatuto. Em referência aos partidos de apoio ao governo, somente é informado que seus posicionamentos não defendem o Estatuto. Em referência aos partidos de apoio ao Governo, é observado que seus posicionamentos não defendem o Estatuto. Nessa questão, é dito e reforçado que os posicionamentos contrários defendem a união homoafetiva. Observa-se que o discurso evangélico é uma questão sensível e funciona, nesse discurso, como legitimação de si. É um argumento forte, nesse discurso, para mostrar ao público leitor da revista Gospelmais que o outro está errado. Já quando o Portal se refere ao Supremo Tribunal Federal (STF), aquele coloca este como pertencente aos críticos do projeto, uma vez que o STF defende o direito de outras famílias. Todas essas vozes surgem para legitimar o discurso da revista contra a pluralidade familiar;

c) Enunciado "social", ideologia e a nomeação: A Revista Gospelmais identifica-se por completo com o discurso religioso e com a conduta dos seus políticos, promovendo uma junção de discursos. Observa-se nesta notícia, no terceiro parágrafo, uma citação direta que acusa um indício do comprometimento dos parlamentares em face do Estatuto: "O Estatuto da Família é apoiado pelos parlamentares da bancada evangélica". O enunciado está completamente associado aos valores do discurso evangélico que compartilha historicamente a defesa da família "sagrada" cristã desde o momento em que escolhem para construir o enunciado palavras impregnadas de valores, como a nomeação do adjetivo "apoiado" referindose ao apoio recebido pela bancada em defesa do Estatuto tradicional da família. Outra nomeação que pode ser destacada é o uso de "esquerdista". Discursivamente, essa nomeação também é fortemente impregnada de valores. Essa nomeação tem funcionado como uma forma negativa de nomear o outro. 
2. Artigo de opinião:

Jesus, segundo consta, era filho de uma virgem, concebido por um Espírito Santo. Maria, sua mãe, vivia com um carpinteiro, José, que se tornou o segundo pai do menino. Em suma, se vivessem no Brasil de 2015, estariam sob risco de ficar de fora do tal Estatuto da Família, a mais nova e retrógrada legislação concebida pelos fundamentalistas do Congresso Nacional, capitaneados pelo suposto cristão Eduardo Cunha (PMDB-RJ). O tal Estatuto da Família é mais um capítulo da cruzada contra os direitos individuais que viceja em um Congresso pautado, cada vez mais, por deputados religiosos (e oportunistas). O texto, aprovado na Comissão de Constituição e Justiça da Câmara Federal, considera família a união única e exclusiva entre um homem e uma mulher. Famílias homoafetivas ou poliafetivas (caso da de Jesus, diga-se) estariam, em tese, fora da lei. A comparação com a virgem de Nazaré, o carpinteiro, a pomba divina e o menino Deus pode até soar desrespeitosa. Mas se trata justamente de debater o desrespeito, neste caso do atual Congresso com parte considerável da sociedade brasileira que vive em núcleos familiares dos mais diversos - casais gays, de lésbicas, de pessoas transexuais, polifamílias, etc. A escalada conservadora tem outros capítulos perversos. Voltou a debate o Projeto de Lei $n^{\circ} 5.069 / 2013$, do próprio Cunha, outra marcha a ré nos direitos humanos e individuais das mulheres. $O$ texto diz que a vítima de estupro só poderá receber atendimento na rede de saúde se antes tiver passado pela polícia e se submetido a um exame de corpo de delito no Instituto Médico Legal. Para piorar a história, o texto ainda quer proibir a distribuição da pílula do dia seguinte em casos de violência sexual. Ou seja, querem forçar as mulheres estupradas a levar adiante uma gravidez fruto de um crime (lembrando que esta mesma mãe e filho ainda não poderão ser chamados de "família", na concepção destes mesmos deputados conservadores).

Tudo isso se dá logo após os mesmos fundamentalistas conseguirem barrar, País afora, a inclusão nos Planos Municipais de Educação do debate sobre a questão de gênero nas escolas. Falar sobre gênero é combater o machismo que endossa a violência sexual que as mulheres vivem no seu dia a dia. É combater bullying nas escolas, que faz com que adolescentes LGBTs estejam no topo dos rankings de suicídios. Ou seja, falar sobre gênero é falar sobre tolerância. E a pressão dos religiosos foi tão grande que até inventaram um termo, a tal "ideologia de gênero", uma mentira que ganhou ares de verdade no debate raso dos conservadores.

\footnotetext{
${ }^{2}$ Artigo de Opinião da Editora Confiança/Revista Carta Capital, de 28/09/15, sob o título Até Jesus ficaria de fora do Estatuto da Família de Cunha / Lide: Projeto é mais um episódio da cruzada contra os direitos individuais dos deputados religiosos e oportunistas. Por Mauricio Moraes.
} 
Na Comissão de Constituição e Justiça, o Estatuto da Família foi aprovado com os votos do PSDB, do PV, do PSC, do PSB, do PSD, do Solidariedade, do PP, do DEM. Votaram contra apenas o PT, o PSOL, o PCdoB e o PTN. Por ora, "transviados" de todo o Brasil não precisam se atemorizar. Caso seja aprovado no plenário da Câmara e do Senado, é praticamente certo que o caso vá parar no Supremo Tribunal Federal, que deve considerar nulo esse ponto do tal Estatuto e derrubar a legislação. É o STF mais uma vez salvando o País da pequenez dos ditos representantes do povo.

Mas é bom lembrar que está justamente aí o ovo da serpente. Há poucos anos, ninguém poderia imaginar que em pleno século XXI deputados e senadores estivessem mais ocupados em legislar sobre o corpo alheio do que sobre questões que realmente importam para o País. Mas aí vieram os deputados pastores, irrigando campanhas com dízimo que não paga imposto e querendo cada vez mais espaço. O resultado está aí: Eduardo Cunha, um dos mais insólitos representantes do conservadorismo religioso brasileiro, na presidência do Legislativo nacional.

Não se enganem...Depois de conquistarem a mídia, pautarem o Congresso, os fundamentalistas religiosos, logo mais, darão o próximo passo - fazer lobby para a indicação do primeiro ministro evangélico do STF. Tempos obscuros.

Análise:

a) Gênero Discursivo: O gênero adotado para discursar sobre o Estatuto da Família pela Revista Carta Capital do dia 28 de setembro de 2015 foi o artigo de opinião, do jornalista Maurício Moraes. O título "Até Jesus ficaria de fora do Estatuto de Cunha" aliado ao título auxiliar "Projeto é mais um episódio da cruzada contra os direitos individuais dos deputados religiosos e oportunistas" já denotam a perspectiva ideológica e dialógica para a qual será direcionado esse artigo, ou seja, no sentido dos que defendem um estatuto contrário ao defendido por Eduardo Cunha, com uma formação diversificada de família. Em outros artigos e notícias da Carta Capital que serviram de corpus ampliado para a verificação do caminho dialógico e valorativo da revista, percebeu-se que também incide uma visão que vai ao encontro da definição de família plural. O movimento argumentativo é traçado da seguinte forma: primeiro parágrafo explica a citação de Jesus no título, colocando-O como pertencente, na época, a uma família nada tradicional, uma vez que José era considerado o segundo pai de Jesus. O segundo parágrafo confirma o primeiro, afirmando que o Estatuto é mais uma forma de ação contra os direitos humanos individuais. $O$ artigo segue acusando os fundamentalistas, conservadores do 
Congresso, que insistem em negar as mudanças nas sociedades contemporâneas, como a questão do debate de gênero na escola, o uso da pílula do dia seguinte, os casos de mulheres estupradas, etc. Num determinado trecho diz-se que: "falar sobre o gênero é falar sobre tolerância", respeito a todos, a todas as formas de amor, a todas as formas de família. Entretanto, o discurso religioso instalado e liderado por Cunha não vem pregando esse respeito. A produção desse gênero discursivo se dá pautada em alusões, havendo em muitos momentos uma referência, "fora do texto", que requer do leitor certa bagagem cultural, como no caso das referências bíblicas;

b) Polifonia: A voz que se destaca nesse artigo é a da Revista Carta Capital, representada pelo jornalista. A todo momento a opinião dele é colocada de forma argumentativa e dialógica. Ele, no primeiro parágrafo, utiliza a citação indireta da Família Sagrada como forma de classificá-la como uma família não tradicional e, logo em seguida, levanta a hipótese de poder se considerar desrespeitosa essa ligação, para então informar que se trata de discutir o desrespeito do Congresso atual com parte considerável da sociedade brasileira. Cita o Projeto de Lei 5.069/2013 de Cunha, que não protege a mulher vítima de estupro, na tentativa de apresentar argumentos e mais argumentos que tornem Cunha réu, como por exemplo, no trecho: "mas é bom lembrar que está justamente aí o ovo da serpente. Há poucos anos, ninguém poderia imaginar que em pleno século XXI deputados e senadores estivessem mais ocupados em legislar sobre o corpo alheio do que sobre questões que realmente importam para o País. Mas aí vieram os deputados pastores (com suas vozes centrífugas à ideia defendida pela revista), irrigando campanhas com dízimo que não paga imposto e querendo cada vez mais espaço. $O$ resultado está aí: Eduardo Cunha, um dos mais insólitos representantes do conservadorismo religioso brasileiro, na presidência do Legislativo nacional.

c) Enunciado, ideologia e nomeação: $\mathrm{O}$ trecho "O tal Estatuto é mais uma cruzada contra os direitos individuais que viceja um Congresso, cada vez mais, por deputados religiosos (oportunistas)" é formado por palavras e expressões que possuem conotações denegridoras em relação ao grupo que defende o Estatuto da Família. O emprego da palavra "tal", nomeando o Estatuto, fornece um ar desrespeitoso, na medida em que o predicativo do sujeito "mais uma cruzada..." confirma esse "tal", ou seja, a implementação do Estatuto é mais uma forma de agir contra os direitos humanos. O verbo "vicejar" é usado ironicamente, uma vez que, na 
SILVA, F.P.S.; REGIS, H.W.F.

maioria dos usos desse verbo, ele se refere ao nascimento de alguma coisa, à germinação de algo frutífero, que não é o caso do Estatuto criticado pela Carta Capital. Há ainda a possível substituição da palavra "religiosos" por "oportunistas", evidenciando a conotação negativa que a revista empresta à Bancada Evangélica. No trecho: "Por ora, 'transviados' de todo o Brasil não precisam se atemorizar", é utilizado o adjetivo "transviados" como forma de nomear ironicamente os "religiosos". Além disso, no artigo de opinião em análise, o discurso da Revista Carta Capital corrobora outros discursos da mesma revista, como visto, por exemplo, no artigo de opinião intitulado "As vítimas da 'sagrada família' que o Congresso quer criar". A revista defende um modelo diversificado de formação familiar, além de especificamente não se identificar com algumas figuras da política, como o próprio Eduardo Cunha. Nesse artigo, a voz do jornalista é a que direciona as vozes constituídas e marcadas que ele quer ativar para justificar sua verdade, por exemplo, o último parágrafo, em que ele reforça sua crítica à Bancada Evangélica, aos fundamentalistas religiosos: "Não se enganem... Depois de conquistarem a mídia, pautarem o Congresso, os fundamentalistas religiosos, logo mais, darão o próximo passo - fazer lobby para a indicação do primeiro ministro evangélico do STF. Tempos obscuros". A carga semântica dos enunciados historicamente situados reverbera a inclinação da revista, mostrando que os signos estão sempre situados no contexto dos eventos discursivos.

\section{Artigo de opinião ${ }^{3}$ :}

\section{Trecho 1:}

O último Censo do Instituto Brasileiro de Geografia e Estatística (IBGE), de 2010, evidencia a evolução das relações sociais e familiares no Brasil. Segundo o levantamento, mães ou pais morando sozinhos com seus filhos; meninas e meninos criados por irmãos mais velhos, tios, avós e/ou bisavós, sem a presença de qualquer um dos pais; adultos sem laços de sangue que dividem um lar e assumem, conjuntamente, a responsabilidade pelas crianças da casa; casais que partem para uma nova união levando os filhos de casamentos anteriores; padrastos e madrastas responsáveis por enteados, entre tantos outros casos, são exemplos desse imenso mosaico de famílias que compõem a sociedade brasileira atual.

\footnotetext{
${ }^{3}$ Artigo de opinião da Editora Publisher Brasil/Revista Fórum, 30/11/2014. Por Erika Kokay: "O que define família é o amor".
}

Revista do SELL, Uberaba/MG (online) - V. 9 n. 2, p. 298-316, jul./dez. - 2020. 
O trecho 1, que corresponde ao primeiro parágrafo do artigo, inicia com a indicação da autora do texto (Erica Kokay) de que fará uso de argumentação que partirá de dados estatísticos para expor o seu posicionamento diante da proposta do Congresso Nacional sobre a formação de famílias plurais. Ela passa a fazer uma costura argumentativa no decorrer de todo texto que, na nossa análise em termos de gênero discursivo, busca se firmar em diversas estratégias linguísticas como a comparação, a descrição, o apelo emotivo e acusações na tentativa de persuadir o leitor na intenção de convencê-lo a adotar a opinião apresentada. No trecho em questão, a autora usa o termo "evolução" das relações socias com o teor de algo "bom", que avançou para outros patamares, o que parece ser entendido, no decorrer de todo texto, como algo a ser adotado, estabelecido como a forma adequada. Em seguida, lista inúmeros exemplos do que ela mesma chama de "imenso mosaico de famílias que compõem a sociedade atual".

\section{Trecho 2:}

Foram listados pelo IBGE 19 diferentes expressões de famílias; no Censo de 2000, eram 11. E, pela primeira vez em nossa história, o Censo, de abrangência nacional, apontou que o modelo tradicional de família - formado por pai/mãe e filhos(as) - deixa de ser maioria no Brasil. Já há cinco anos, os novos lares - inclusive os constituídos por pessoas solteiras que moram sozinhas e por famílias homoafetivas - somavam 28.647 milhões de residências: 28.737 a mais do que as com a formação "tradicional". Esses arranjos "não tradicionais" estavam presentes em 50,1\% dos domicílios brasileiros, à época do Censo.

O trecho 2, que corresponde ao $2^{\circ}$ parágrafo do texto, traz duas vezes o termo, extremamente pejorativo, "tradicional", já destacando dois campos: os não tradicionais e os tradicionais. Porém usa o termo "arranjos" que tem também uma denotação pejorativa no sentido de algo arranjado, arrumado, o que não seria coerente quando a intenção é o convencimento. Aspectos da citada pesquisa que possam revelar causas e consequências das "relações sociais e familiares no Brasil" se existem não foram mencionados. Nos trechos adiante, fica evidente que o aspecto da dialogicidade e da alteridade (incorporar o outro no discurso), elementos comuns em um artigo de opinião, vêm à tona na busca da persuasão do leitor, todavia omitir uma discussão sobre os efeitos da "evolução das relações sociais e familiares" parece não corroborar com o intento principal.

Após a análise desses dois primeiros parágrafos, faremos uma abordagem geral dos demais parágrafos, fazendo recortes para análises, obedecendo à sequência do texto. Nesse sentido, quanto ao aspecto gênero discursivo, o tema é polêmico (definição 


\section{SILVA, F.P.S.; REGIS, H.W.F.}

de família nos tempos atuais), e a autora, nos parágrafos 3 e 4, faz referência à Constituição Brasileira, continuando a adotar a estratégia de usar citações alheias. No terceiro parágrafo, a autora afirma, em tom de oposição: "Mas aqui falamos de pessoas, hetero e homossexuais, nem sempre unidas por laços de sangue, mas necessariamente ligadas por fortes laços de afeto, e que constituíram esses novos núcleos de convívio. Juntas ou sozinhas, essas pessoas indubitavelmente formaram famílias". Nesse trecho, a articulação coesiva por meio de um articulador argumentativo, no caso a conjunção adversativa mas, começa a operar no sentido de trabalhar contra-argumentos que possam sustentar o conceito de família que defende. No quarto parágrafo, para argumentar em defesa do que foi citado no parágrafo anterior, que "hetero e homossexuais [...] devem ter sua existência e seus direitos respeitados por todas e todos os brasileiros, como assegura a nossa própria Constituição", afirma, em sua análise, que "A Carta Magna reconhece a família como base da sociedade [...] mas não classifica o que é família." A partir dessa premissa, a autora passa a usar outros articuladores argumentativos (conjunções aditivas, adversativas, explicativas) de forma incisiva e radical, defendendo sua tese com argumentos e contra-argumentos.

No quinto parágrafo, a autora continua a discorrer sobre os princípios constitucionais, a citar a Constituição, defendendo que eles não devem ser suprimidos, e explica: "porque quiseram os constituintes garantir ao povo brasileiro direitos que não seriam ameaçados por eventuais debates, divergências ou pressões políticas, partidárias, sociais, religiosas, de opiniões ou de quaisquer outras naturezas". É, principalmente desse ponto do texto, que em termos de polifonia, podemos fazer uma análise mais acurada ainda sobre o artigo de opinião em questão. Podemor entender que a deputada Erika Kokay estabelece um jogo argumentativo com o propósito de trazer evidências metadiscursivas em prol da definição da pluralidade das famílias. A princípio, utiliza as vozes legitimadoras do IBGE e do Supremo Tribunal Federal, e mais adiante depoimentos de famílias plurais que mostram a comprovação da possibilidade de serem felizes.

Como vimos, Erika Kokay cita a Constituição Federal quando alega que a "Carta Magna reconhece a família como base da sociedade e lhe confere especial proteção do Estado, mas não classifica o que é família..." e infere que a Constituição não estabelece um modelo único de família. No seu discurso, a polifonia, sendo representada pelas vozes citadas, e a intertextualidade - como a relação dialógica entre textos - assumem várias direções, mas possuem um único sentido: a defesa da diversidade de famílias. A deputada defende também várias direções por ter, inclusive, nesse artigo de opinião, alguns momentos em que aborda o discurso dos "defensores do Estatuto" como seu 


\section{SILVA, F.P.S.; REGIS, H.W.F.}

próprio ponto de vista, dizendo que eles, na condição de serem maioria, acham-se no direito de defender um modelo de comportamento padrão.

A partir do quinto parágrafo, ao citar "pressões... religiosas", a autora direciona o foco para o que ela nomeia, no sexto parágrafo, de "forças conservadoras com fortes motivações religiosas" e usa o enunciado "...tentam, portanto, golpear de morte nossa Constituição, ao propor um Estatuto da Família que só considera como núcleo familiar aquele formado por um homem, uma mulher e seus descendentes". Desse ponto do texto até o último parágrafo, em termos de enunciado, ideologia e nomeação, o que se percebe, no artigo escrito por Erica Kokay, é que há uma tentativa argumentativa e discursiva de ir além de uma metalinguagem. A deputada direciona a definição tradicional de família para uma nova dimensão, ou seja, ela rompe no texto com o paradigma da relação da linguagem com o objeto, da relação do nome família com o seu sentido mais tradicional. Para isso, ela emprega as expressões nominais: "coisa do passado", referindo-se ao modelo tradicional de família; "forças conservadoras", "fortes motivações religiosas", remetendo aos deputados evangélicos que defendem o Estatuto. Nesse momento, a deputada reflete sobre a questão da laicidade do Estado e o defende para garantir simultaneamente a liberdade de todos e a liberdade de cada um. Adjetivos evidenciando sua insatisfação pelo Estatuto da Família aparecem na conclusão do artigo: "lamentável, nesse sentido, que o relatório sobre o Estatuto da Família esterilize os afetos das relações familiares", "Uma tentativa cruel de negar a diversidade". Há também alguns recursos linguísticos, como o uso do adjetivo e de verbos, os quais a deputada utiliza no intuito de depreciar os que militam em prol do Estatuto: "Os defensores do Estatuto se arvoram da falaciosa condição de representantes", "o Estatuto da família retroage no ponto de vista legal".

\section{CONSIDERAÇÕES FINAIS}

As análises revelam, a partir da materialidade linguística, que as instituições jornalísticas observadas operam seus discursos a partir dos aspectos axiológicos que as constituem. Mesmo sendo esses "aspectos" relacionados às ideologias das revistas, esse alinhamento está diretamente associado ao público leitor das instituições, uma vez que não seria "coerente" por parte dos produtores de informações publicar notícias que não se coadunassem com o comprador dessas revistas. Dessa forma, todo o evento discursivo sobre o conceito de família está impregnado de dialogismo, no sentido amplo da interação discursiva, da alteridade, do olhar para o outro colocando-se em seu lugar, de dizer para o outro o que ele quer ouvir. Nessa questão, segundo Fiorin (2003, p. 36), mesmo que os 
outros sejam o inferno, o homem está inelutavelmente preso ao outro naquilo que há de mais caracteristicamente humano: a linguagem. A alteridade é uma dimensão constitutiva do discurso. Não há identidade discursiva sem a presença do outro.

Sobre o embate referente ao conceito de família, a mídia apresenta pontos de vista diferentes, em que cada um defende sua pretensa verdade. Sabe-se, contudo, que qualquer enunciação, por mais significativa e completa que seja, constitui apenas uma fração de uma corrente de comunicação verbal ininterrupta. Mas, nesse embate, existe algo que a linguagem pragmaticamente suscita e modifica: o discurso sobre o conceito de família já não é único e vêm ocorrendo mudanças sociais devido ao processo lento, mas ininterrupto, de forças centrífugas que rompem paradigmas e valores hegemônicos.

\section{REFERÊNCIAS}

BAKHTIN, Mikhail. O Discurso no romance in: BAKHTIN, Mikhail. Questões de Literatura e de estética: a teoria do romance. $3^{\text {a }}$ edição. São Paulo: Unesp Hucitec, [1975] 1993.

Estética da criação verbal / Mikhail Mikhailovich Bakhtin; prefácio à edição francesa Tzvetan Todorov; introdução e tradução do russo Paulo Bezerra - 6 a $^{\mathbf{a}}$ ed. - São Paulo: editora WMF Martins Fontes, 2011.

Problemas da Poética de Dostoiévski. Tradução do russo, notas e prefácio de Paulo Bezerra. 4. ed. Rio de Janeiro: Forense Universitária, 2008.

BAKHTIN, Mikail.; VOLÓCHINOV, Valentin. Discurso na vida e discurso na arte: sobre poética sociológica. Tradução de Carlo Alberto Faraco e Cristóvão Tezza,1926. Mimeografado.

FIORIN, José Luiz. Introdução ao pensamento de Bakhtin. São Paulo: Ática, 2003. HALL, Stuart. A Identidade cultural na Pós-modernidade. Trad. Tomaz T. Silva e Guacira L. Louro. 4 ed. Rio de Janeiro: DP\&A, 2000.

JAKUBINSKIJ, Lev. Sobre a fala dialogal. Tradução de Dóris de Arruda Cunha, Suzana Leite Cortez. São Paulo: Parábola editorial, 2015.

MARCUSCHI, Luis Antônio. A. Produção textual, análise de gêneros e compreensão. São Paulo: Parábola Editorial, 2008.

MOIRAND, Sophie. De l'aire de la page à l' hyperstructure et à l' écran: comment lire et analyser la presse quotidienne ordinaire. CAUCE, Revista Internacional de Filologia y Didáctica, n. 29, p. 295-320, 2006.

RECHDAN, Maria Letícia de Almeida. Dialogismo ou polifonia? Revista Ciências Humanas, Taubaté, v. 9, n. 1, jan. /jun. 2003.

SIBLOT, Paul. De I'un à l'autre. Dialectique et dialogisme de la nomination identitaire. In: Bres, J. et al. (Eds). L'autre en discours. Université Montpellier 3, 1998. 
VOLÓCHINOV, Valentin. A construção da enunciação e outros ensaios. São Carlos: Pedro \& João editores, 2013.

Marxismo e filosofia da linguagem: problemas fundamentais do método sociológico na ciência da linguagem / Valentin Volóchinov; tradução, notas e glossário de Sheila Grillo e Ekaterina Vólkova Américo; ensaio introdutório de Sheila Grillo -- São Paulo: Editora 34, 2017.

Como citar este artigo (ABNT)

SILVA, F.P.S.; REGIS, H.W.F. Vieses jornalísticos sobre o conceito de família à luz da teoria dialógica do discurso. SELL, Uberaba, MG, v. X, n. X, p. XXX-XXX, 2019. Disponível em: <inserir link de acesso>. Acesso em: inserir dia, mês e ano de acesso. DOI: inserir link do DOI.

Como citar este artigo (APA)

Silva, F.P.S. \& Regis, H.W.F. (2020). Vieses jornalísticos sobre o conceito de família à luz da teoria dialógica do discurso. SELL, X(X), XXX-XXX. Recuperado em: inserir dia, mês e ano de acesso de inserir link de acesso. DOI: inserir link do DOI. 